\title{
Effect of Selected Organic Residues and Inorganic Fertilizers on the Performance of Okra (Abelmoschus esculentus)
}

\author{
T.O. Amodu, G.O. Dayo-Olagbende*, and O.O. Akingbola \\ Crop, Soil and Pest Management, School of Agriculture and Agricultural Technology, Federal \\ University of Technology, Akure, Nigeria \\ "phemmieisrafel@gmail.com
}

Keywords: Aspilia africana, Gliricidia sepiu, Fertilizers, Organic residues, Okra.

\begin{abstract}
In a bid to evaluate the effect of selected organic residues and inorganic on the performance of okra (Abelmoschus esculentus), a concurrent experiment was conducted using Gliricidia sepium and Aspilla africana as the source of organic residue while $\mathrm{N}: \mathrm{P}: \mathrm{K}$ and urea were used as the sources of inorganic fertilizers. The materials were applied solely and in combinations to give a total of nine treatments. The land area used was $28 \mathrm{~m}$ by $11 \mathrm{~m}$ partition into 9 plots and replicated three times to give a total of 27 experimental units. The experiment was laid out in a randomized Complete Black Design. Okra variety lady finger was planted at a spacing of $60 \mathrm{~cm}$ by $45 \mathrm{~cm}$ at a rate of three seeds per hole which was later thinned to one plant per stand. The treatments were applied two weeks after planting. Ten plants were tagged to determine the growth and yield parameters. Data collected were subjected to Analysis of Variance using SPSS 16.00 version and mean separation was done using Duncan Multiple Range Test. It was discovered that treatments containing a combination of N:P:K, urea and gliricidia sepium ( $\left.\mathrm{T}_{9}\right)$ gave the best in terms of growth parameter and yield on site 1 while on site 2 a combination of $\mathrm{N}: \mathrm{P}: \mathrm{K}$, urea and Aspilia africana $\left(\mathrm{T}_{8}\right)$ gave the best. This shows the okra responds well to applications of organic residues together with inorganic fertilizers.
\end{abstract}

\section{Introduction}

Okra is a vegetable crop that belongs to the genus Abelmoschus, family Malvaceae and has two main species: Abelmoschus esculentus (L.) Moench and Abelmoschus caillei. Okra is a heat-loving vegetable in the Hibiscus family. It is cultivated in tropical, subtropical and warm temperate regions around the world [10] and plays an important role in the human diet by supplying protein, fats, minerals and vitamins that are usually deficient in the sample food [5]. The nutritional importance of okra pod has reawakened interest in bringing the crop into commercial production. Despite the nutritional value of okra, its optimum yields $\left(2-3\right.$ tha $\left.^{-1}\right)$ and quality have not been attained in the tropical countries partly because of a continued decline in soil fertility [4]. Okra (Abelmoschus esculentus L. Moench) was domesticated in West and Central Africa, but is now widely cultivated throughout the tropics primarily for local consumption. In Nigeria, it ranks third in terms of consumption and production area following tomato and pepper [6]. The green pods are rich sources of vitamins, calcium, potassium, and other minerals [5]. At maturity, fruits turn brown and split into segments, only the tender, unripe fruit is eaten. Okra is an allopolyploid of uncertain parentage (proposed parents include Abelmoschus ficulneus, A. luherculatus and a reported "diploid" form of okra). Truly wild (as opposed to naturalized) populations are not known with certainty and the species may be a cultigen. Okra grows best at temperatures between 75 and $90^{\circ} \mathrm{F}$ and should not be planted in the spring before the soil temperature is about $65^{\circ} \mathrm{F}$ at the 4 -inch depth [2]. The optimum soil temperature or seed germination is 70 to $95^{\circ} \mathrm{F}$. The crop can be grown on all soil' types, although sandy loam soils of high organic matter are the most desirable. It is important that the soil be welldrained. Okra is plant in full sun for best productivity [1]. It requires a warm, humid condition to produce an abundant crop. It can also be sensitive to salt spray; however, proper fertilizing will help maximize the number of fruits. 
Tropical soils are adversely affected by suboptimal soil fertility and erosion, causing deterioration of the nutrient status and change in soil organism populations [17]. Use of inorganic fertilizers can improve crop yields, but its use is limited due to scarcity, high cost, nutrient imbalance and soil acidity [9]. Use of organic manures like poultry manure as a mean of maintaining and increasing soil fertility has been advocated because nutrients contained in manure are released more slowly and are stored for a longer time in the soil ensuring longer residual effects, improved root development and higher crops yield [12]. More so, Green manure has a milder smell than the dung of carnivores or omnivores, making it easy to work with [11].

The effects of fertilizer on the growth and yield of okra had been reported in various studies $[16,14]$. In the experiment conducted by Uka et al. [15] on the relative effects of inorganic and organic fertilizer on the growth of okra, it was observed that both fertilizer types produced significantly higher value for plant height, fresh weight, leaf area and dry weight compared to the control without fertilizer. The continuous use of mineral fertilizer in tropical soils which had been associated with reduced crop yield, increased soil acidity and nutrient imbalance necessitated investigation on the combination of organic materials and mineral fertilizer in fertilizer management to improve soil fertility [8]. Organic residues are considered as good sources of nutrient to improve soils. Compared to manures, these residues are found around farmyards and edges of roads, and if properly managed can improve soil fertility without the concern of transportation.

The nutritional importance of okra pod has reawakened interest in bringing the crop into commercial production. Despite the nutritional value of okra, its optimum yields $\left(2-3 \mathrm{tha}^{-1}\right)$ and quality have not been attained in the tropical countries partly because of a continued decline in soil fertility [4]. Therefore, the objective of this study is to determine the effect of selected organic residues and inorganic fertilizer on okra performance.

\section{Materials and Methods}

\section{Experimental Site Description}

The study was conducted between January and July 2015 at the research and Teaching farm of Federal University of Technology Akure. The location has a bimodal rainfall of 1250 to $1460 \mathrm{~mm}$ with mean annual rainfall of $1367 \mathrm{~mm}$. Temperature is almost uniform throughout the year $23-32^{\circ} \mathrm{C}$ with little deviation from mean annual of $27^{\circ} \mathrm{C}$. The mean total sunshine hour is about 2000 hours with mean annual radiation of about $130 \mathrm{kcal} \mathrm{cm}^{-3} \mathrm{year}^{-1}$. The area falls within the high forest zone where the rich tropical forests once thrived. The location has a tropical humid climate with distinct wet and dry seasons.

\section{Land Preparation and Experimental Design}

The site was cleared, measured out, pegged and beds were constructed manually with hoe. The area used was measured to be $28 \mathrm{~m}$ by $11 \mathrm{~m}$ in size having a total of 27 plots. Each plot measured $2 \mathrm{~m}$ by $2 \mathrm{~m}$. The experimental field was made up of three blocks with $1 \mathrm{~m}$ Alleyway within plots. The experiment was laid out in a Randomized Complete Block Design with each treatment replicated three times.

\section{Treatments}

The treatments tested with application rates were:

1. $\mathrm{T}_{1}=$ Control

2. $\mathrm{T}_{2}=6 \mathrm{t} \mathrm{ha}^{-1}$ Aspilia africana

3. $\mathrm{T}_{3}=6 \mathrm{t} \mathrm{ha}^{-1}$ Gliricidia sepium

4. $\mathrm{T}_{4}=75 \mathrm{~kg} \mathrm{ha}^{-1} \mathrm{NPK}$

5. $\mathrm{T}_{5}=75 \mathrm{~kg} \mathrm{ha}^{-1} \mathrm{NPK}+6 \mathrm{t} \mathrm{ha}^{-1}$ Gliricidia sepium

6. $\mathrm{T}_{6}=75 \mathrm{~kg} \mathrm{ha}^{-1} \mathrm{NPK}+6 \mathrm{t} \mathrm{ha}^{-1}$ Aspilia africana

7. $\mathrm{T}_{7}=75 \mathrm{~kg} \mathrm{ha}^{-1} \mathrm{NPK}+50 \mathrm{~kg} \mathrm{ha}^{-1}$ Urea

8. $\mathrm{T}_{8}=6 \mathrm{t} \mathrm{ha}^{-1}$ Aspilia africana $+75 \mathrm{kgha}^{-1} \mathrm{NPK}+50 \mathrm{~kg} \mathrm{ha}^{-1}$ Urea

9. $\mathrm{T}_{9}=6 \mathrm{t} \mathrm{ha}^{-1}$ Gliricidia sepium $+75 \mathrm{kgha}^{-1} \mathrm{NPK}+50 \mathrm{~kg} \mathrm{ha}^{-1}$ Urea 


\section{Planting and Cultural Practices}

The variety of okra used for the experiment was lady finger; the seeds were purchased at the Agricultural Development Program Headquarter (ADP.) Akure. The seeds were planted at the rate of three seeds per hole with a spacing of $60 \mathrm{~cm}$ by $45 \mathrm{~cm}$. Two weeks after planting ( 2 wap), the seedlings were thinned to one plant per stand.

Treatments were applied two weeks after planting, $75 \mathrm{~kg}$ of NPK was used as againt the recommended rate of $150 \mathrm{kgha}^{-1}$ proposed by Omotoso and Shittu [13]. This is done so as to see if the combination of NPK at the rate $75 \mathrm{kgh}^{-1}$ with the other treatment will supply the deficit. Manual weeding was done twice throughout the duration of the experiment. Ten plants per plot were selected and tagged to determine the growth and yield parameters. The growth parameters assessed included plant height measured with the use of meter rule, stem girth measured with the use of vainer caliper, number of leaves was counted, leaves length measured with the use of meter rule. Successive harvesting was done five days interval as fruits reached marketable size. The number of fruits was counted on each occasion and fresh pod weight obtained to determine yield.

\section{Analysis of Data}

All data collected during the experiment were subjected to statistical analysis of variance (ANOVA) to determine the level of significance between the treatments using Statistical Package for the Social Science (SPSS) software version 16.00. Means of significant treatments were further separated using Duncan multiple range test (DMRT) $\mathrm{P} \leq 0.05$.

\section{Results}

\section{Pre-Planting Soil Chemical Properties}

Table 1 shows pre-planting soil chemical soil analysis. The $\mathrm{pH}$ of the experimental soils varied between 5.13 to 5.78 , total $\mathrm{N} 0.11$ to $0.28 \%$, available $\mathrm{P} 7.20$ to $6.47 \mathrm{mg} \mathrm{kg}^{-1}$, exchangeable $\mathrm{K} 0.08$ to $0.13, \mathrm{Ca} 1.8$ to $2.6, \mathrm{Mg} 0.05$ to $1.00 \mathrm{cmol} / \mathrm{kg}$, and organic matter $(\mathrm{OM}) 1.32$ to $2.21 \%$. The soil is acidic, low in N, exchangeable K and OM [3].

\section{Effect of Organic Mulch and Inorganic Fertilizer on Plant height (cm) and Stem girth (cm) of okra}

Table 2 and 3 present the effect of Organic Residue and Inorganic Fertilizers of plant height and stem girth of okra plant respectively. The same trend was observed for both plant height and girth at both sites. Through the growth period of the okra plant, $\mathrm{T}_{9}$ recorded the tallest plant with the widest girth while $\mathrm{T}_{1}$ (control) gave the lowest. However, $\mathrm{T}_{5}$ and $\mathrm{T} 8$ were not significantly different from the $\mathrm{T}_{9}$. This phenomenon is as a result of the availability of $\mathrm{N}$ in the soil. $\mathrm{N}$ is responsible for proper vegetative growth of plant and the treatment combination $\left(\mathrm{T}_{9}, \mathrm{~T}_{8}, \mathrm{~T}_{5}\right)$ made $\mathrm{N}$ readily available throughout the growth period of the plant.

Table 1. Pre-planting soil properties.

\begin{tabular}{llc}
\hline Soil properties & \multicolumn{2}{c}{ Experimental sites } \\
& Site 1 & Site 2 \\
\hline Sand (\%) & 62.80 & 60.80 \\
Silt $(\%)$ & 16.00 & 14.00 \\
Clay $(\%)$ & 21.20 & 25.20 \\
Bulk Density $(\mathrm{g} / \mathrm{cm} 3)$ & 1.54 & 1.48 \\
$\mathrm{pH}$ & 5.78 & 5.13 \\
Organic matter $(\%)$ & 2.64 & 2.28 \\
Total nitrogen $(\%)$ & 0.11 & 0.28 \\
Available $\mathrm{P}(\mathrm{mg} / \mathrm{kg})$ & 7.20 & 30.86 \\
Exchangeable $\mathrm{K}(\mathrm{cmol} / \mathrm{kg})$ & 0.15 & 0.12 \\
Exchangeable $\mathrm{Ca}(\mathrm{cmol} / \mathrm{kg})$ & 2.00 & 2.10 \\
Exchangeable $\mathrm{Mg}(\mathrm{cmol} / \mathrm{kg})$ & 0.90 & 1.00 \\
\hline
\end{tabular}


Table 2. Effect of Organic Mulch and Inorganic Fertilizer on plant height $(\mathrm{cm})$ of okra at weeks after treatment application.

\begin{tabular}{llll|lll}
\hline Treatment & \multicolumn{3}{c|}{ SITE 1 } & \multicolumn{3}{c}{ SITE 2 } \\
& \multicolumn{1}{c}{4} & \multicolumn{1}{c}{6} & \multicolumn{1}{c}{4} & \multicolumn{1}{c}{6} & \multicolumn{1}{c}{8} \\
\hline T1 & $30.78 \mathrm{~d}$ & $41.13 \mathrm{c}$ & $45.00 \mathrm{c}$ & $32.13 \mathrm{c}$ & $40.31 \mathrm{c}$ & $45.93 \mathrm{c}$ \\
T2 & $36.70 \mathrm{c}$ & $47.39 \mathrm{bc}$ & $51.90 \mathrm{bc}$ & $36.21 \mathrm{bc}$ & $48.09 \mathrm{ab}$ & $51.62 \mathrm{bc}$ \\
T3 & $37.30 \mathrm{c}$ & $48.27 \mathrm{ab}$ & $52.00 \mathrm{~b}$ & $37.61 \mathrm{bc}$ & $47.32 \mathrm{~b}$ & $51.02 \mathrm{bc}$ \\
T4 & $39.00 \mathrm{~b}$ & $49.07 \mathrm{a}$ & $53.53 \mathrm{~b}$ & $37.34 \mathrm{bc}$ & $47.38 \mathrm{~b}$ & $52.87 \mathrm{bc}$ \\
T5 & $38.13 \mathrm{~b}$ & $48.77 \mathrm{ab}$ & $55.87 \mathrm{ab}$ & $39.09 \mathrm{ab}$ & $49.10 \mathrm{a}$ & $53.21 \mathrm{ab}$ \\
T6 & $35.14 \mathrm{bc}$ & $47.49 \mathrm{~b}$ & $52.17 \mathrm{~b}$ & $36.12 \mathrm{bc}$ & $48.13 \mathrm{ab}$ & $53.06 \mathrm{ab}$ \\
T7 & $40.03 \mathrm{ab}$ & $47.72 \mathrm{~b}$ & $52.32 \mathrm{~b}$ & $38.17 \mathrm{~b}$ & $46.93 \mathrm{bc}$ & $51.13 \mathrm{bc}$ \\
T8 & $40.19 \mathrm{ab}$ & $48.58 \mathrm{ab}$ & $54.11 \mathrm{ab}$ & $39.11 \mathrm{ab}$ & $48.09 \mathrm{ab}$ & $52.09 \mathrm{~b}$ \\
T9 & $41.07 \mathrm{a}$ & $48.76 \mathrm{~b}$ & $56.12 \mathrm{a}$ & $40.59 \mathrm{a}$ & $49.01 \mathrm{a}$ & $54.14 \mathrm{a}$ \\
\hline
\end{tabular}

Each Value is a mean of three replicates. Data followed by the same alphabet along the columns are not significantly different at $\mathrm{p}=0.05$ using Duncan's Multiple Range Test (DMRT)

Table 3. Effect of Organic Mulch and Inorganic Fertilizer on stem (cm) girth of okra at weeks after treatment application.

\begin{tabular}{llll|lll}
\hline Treatment & \multicolumn{3}{c|}{ SITE 1 } & \multicolumn{3}{c}{ SITE 2 } \\
& 4 & 6 & 8 & 4 & 6 & \multicolumn{1}{c}{8} \\
\hline T1 & $0.32 \mathrm{~d}$ & $0.40 \mathrm{c}$ & $0.44 \mathrm{c}$ & $0.30 \mathrm{c}$ & $0.39 \mathrm{c}$ & $0.42 \mathrm{c}$ \\
T2 & $0.38 \mathrm{c}$ & $0.52 \mathrm{a}$ & $0.54 \mathrm{ab}$ & $0.38 \mathrm{~b}$ & $0.51 \mathrm{a}$ & $0.54 \mathrm{ab}$ \\
T3 & $0.39 \mathrm{c}$ & $0.48 \mathrm{ab}$ & $0.52 \mathrm{~b}$ & $0.38 \mathrm{~b}$ & $0.49 \mathrm{ab}$ & $0.55 \mathrm{a}$ \\
T4 & $0.40 \mathrm{bc}$ & $0.48 \mathrm{ab}$ & $0.55 \mathrm{ab}$ & $0.41 \mathrm{ab}$ & $0.48 \mathrm{ab}$ & $0.52 \mathrm{ab}$ \\
T5 & $0.45 \mathrm{a}$ & $0.47 \mathrm{~b}$ & $0.56 \mathrm{a}$ & $0.43 \mathrm{a}$ & $0.48 \mathrm{ab}$ & $0.54 \mathrm{ab}$ \\
T6 & $0.41 \mathrm{ab}$ & $0.49 \mathrm{ab}$ & $0.55 \mathrm{ab}$ & $0.37 \mathrm{~b}$ & $0.47 \mathrm{~b}$ & $0.53 \mathrm{~b}$ \\
T7 & $0.42 \mathrm{ab}$ & $0.47 \mathrm{~b}$ & $0.55 \mathrm{ab}$ & $0.43 \mathrm{a}$ & $0.47 \mathrm{~b}$ & $0.54 \mathrm{ab}$ \\
T8 & $0.45 \mathrm{a}$ & $0.51 \mathrm{a}$ & $0.56 \mathrm{a}$ & $0.43 \mathrm{a}$ & $0.49 \mathrm{ab}$ & $0.54 \mathrm{ab}$ \\
T9 & $0.45 \mathrm{a}$ & $0.52 \mathrm{a}$ & $0.56 \mathrm{a}$ & $0.43 \mathrm{a}$ & $0.50 \mathrm{a}$ & $0.55 \mathrm{a}$ \\
\hline
\end{tabular}

Each Value is a mean of three replicates. Data followed by the same alphabet along the columns are not significantly different at $\mathrm{p}=0.05$ using Duncan's Multiple Range Test (DMRT)

\section{Effect of Organic Mulch and Inorganic Fertilizer on number of leaves and Leaf Length (cm) of okra}

Table 4 and 5 present the effect of Organic Residue and inorganic fertilizer on leaf number leaf length $(\mathrm{cm})$ of okra plants respectively. The same trend was observed at the two sites, $\mathrm{T}_{7}$ recorded the longest leaf while $\mathrm{T}_{1}$ (control) gave the shortest leaf. The second longest leaf and highest leaf number came from $T_{9}$ but there was no significant difference between $T_{7}$ and $T_{9}$. Nitrogen aids vegetative growth of plants and the application of Urea which is a single or straight fertilizer combined with NPK makes Nitrogen available in the soil. The okra plant thereby had supply of $\mathrm{N}$ for metabolism from the $\mathrm{T}_{7}$. This agrees with the findings of R.L. Walker et al. [7] who stated that nitrate only tended to accumulate in plant tissues when its supply is adequate. By comparison, plants forced to rely solely on their internal reserves were never able to mobilize and redistribute $\mathrm{N}$ between tissues quickly enough to prevent reductions in growth rate as their tissue $\mathrm{N}$ reserves declined. 
Table 4. Effect of Organic Mulch and Inorganic Fertilizer on number of leaves of okra at weeks after treatment application.

\begin{tabular}{llll|lll}
\hline Treatment & \multicolumn{3}{c|}{ SITE 1 } & \multicolumn{3}{c}{ SITE 2 } \\
& \multicolumn{1}{c}{4} & 6 & 8 & 4 & 6 & \multicolumn{1}{c}{8} \\
\hline T1 & $14.67 \mathrm{~b}$ & $20.57 \mathrm{c}$ & $25.73 \mathrm{c}$ & $12.89 \mathrm{~b}$ & $16.01 \mathrm{c}$ & $22.00 \mathrm{c}$ \\
T2 & $17.39 \mathrm{ab}$ & $23.28 \mathrm{bc}$ & $27.84 \mathrm{~b}$ & $14.81 \mathrm{ab}$ & $19.58 \mathrm{bc}$ & $25.12 \mathrm{bc}$ \\
T3 & $19.31 \mathrm{a}$ & $24.12 \mathrm{~b}$ & $29.91 \mathrm{ab}$ & $18.48 \mathrm{a}$ & $23.87 \mathrm{~b}$ & $28.01 \mathrm{~b}$ \\
T4 & $19.33 \mathrm{a}$ & $25.34 \mathrm{ab}$ & $29.00 \mathrm{ab}$ & $19.67 \mathrm{a}$ & $25.11 \mathrm{a}$ & $28.66 \mathrm{~b}$ \\
T5 & $19.33 \mathrm{a}$ & $25.23 \mathrm{ab}$ & $29.00 \mathrm{ab}$ & $18.72 \mathrm{a}$ & $24.14 \mathrm{ab}$ & $30.10 \mathrm{a}$ \\
T6 & $20.67 \mathrm{a}$ & $26.81 \mathrm{a}$ & $30.00 \mathrm{a}$ & $19.51 \mathrm{a}$ & $24.36 \mathrm{ab}$ & $29.14 \mathrm{ab}$ \\
T7 & $20.72 \mathrm{a}$ & $25.37 \mathrm{ab}$ & $29.18 \mathrm{ab}$ & $18.93 \mathrm{a}$ & $23.69 \mathrm{~b}$ & $29.28 \mathrm{ab}$ \\
T8 & $20.00 \mathrm{a}$ & $26.04 \mathrm{a}$ & $29.33 \mathrm{ab}$ & $20.03 \mathrm{a}$ & $23.69 \mathrm{~b}$ & $29.31 \mathrm{ab}$ \\
T9 & $20.73 \mathrm{a}$ & $26.17 \mathrm{a}$ & $30.19 \mathrm{a}$ & $19.79 \mathrm{a}$ & $25.42 \mathrm{a}$ & $29.68 \mathrm{ab}$ \\
\hline
\end{tabular}

Each Value is a mean of three replicates. Data followed by the same alphabet along the columns are not significantly different at $\mathrm{p}=0.05$ using Duncan's Multiple Range Test (DMRT)

Table 5. Effect of Organic Residue and Inorganic Fertilizer on Leaf Length $(\mathrm{cm})$ of okra at weeks after treatment application.

\begin{tabular}{llll|lll}
\hline Treatment & \multicolumn{3}{c|}{ SITE 1 } & \multicolumn{3}{c}{ SITE 2 } \\
& \multicolumn{1}{c}{4} & \multicolumn{1}{c}{8} & \multicolumn{1}{c}{8} & \multicolumn{1}{c}{6} & \multicolumn{1}{c}{6} \\
\hline T1 & $28.97 \mathrm{e}$ & $49.23 \mathrm{~d}$ & $75.33 \mathrm{~d}$ & $22.11 \mathrm{~d}$ & $40.27 \mathrm{e}$ & $75.11 \mathrm{c}$ \\
T2 & $35.48 \mathrm{~d}$ & $54.57 \mathrm{~cd}$ & $88.60 \mathrm{c}$ & $37.27 \mathrm{~cd}$ & $48.33 \mathrm{~d}$ & $75.19 \mathrm{c}$ \\
T3 & $35.69 \mathrm{~d}$ & $61.13 \mathrm{c}$ & $86.19 \mathrm{c}$ & $34.26 \mathrm{~cd}$ & $53.47 \mathrm{~cd}$ & $85.40 \mathrm{bc}$ \\
T4 & $46.16 \mathrm{c}$ & $71.57 \mathrm{bc}$ & $93.53 \mathrm{ab}$ & $42.62 \mathrm{c}$ & $61.66 \mathrm{c}$ & $92.39 \mathrm{~b}$ \\
T5 & $55.12 \mathrm{bc}$ & $80.30 \mathrm{~b}$ & $93.47 \mathrm{ab}$ & $49.83 \mathrm{c}$ & $80.01 \mathrm{bc}$ & $93.17 \mathrm{ab}$ \\
T6 & $48.45 \mathrm{c}$ & $83.31 \mathrm{ab}$ & $93.51 \mathrm{ab}$ & $49.84 \mathrm{bc}$ & $82.11 \mathrm{~b}$ & $94.64 \mathrm{bc}$ \\
T7 & $59.10 \mathrm{ab}$ & $86.42 \mathrm{a}$ & $99.73 \mathrm{a}$ & $57.68 \mathrm{a}$ & $89.46 \mathrm{a}$ & $95.6 \mathrm{a}$ \\
T8 & $58.81 \mathrm{~b}$ & $86.72 \mathrm{a}$ & $93.11 \mathrm{~b}$ & $58.36 \mathrm{a}$ & $82.91 \mathrm{~b}$ & $92.48 \mathrm{bc}$ \\
T9 & $59.93 \mathrm{a}$ & $84.78 \mathrm{ab}$ & $95.41 \mathrm{ab}$ & $51.9 \mathrm{~b}$ & $83.00 \mathrm{ab}$ & $94.89 \mathrm{a}$ \\
\hline
\end{tabular}

Each Value is a mean of three replicates. Data followed by the same alphabet along the columns are not significantly different at $\mathrm{p}=0.05$ using Duncan's Multiple Range Test (DMRT)

\section{Effect of Organic Mulch and Inorganic Fertilizer on the yield of okra}

Fig. 1 shows the effect of organic residues and inorganic fertilizers on the yield of okra plant on both site 1 and site 2 . The same trend was observed on both sites with the control (T1) recording the lowest yield among the treatments. The highest yield on site 1 is $\mathrm{T}_{9}(6 \mathrm{t} / \mathrm{ha}$ Gliricidia sepium + $75 \mathrm{~kg} \mathrm{ha}^{-1} \mathrm{NPK}+50 \mathrm{~kg} \mathrm{ha}^{-1}$ Urea $)$ while on site $2, \mathrm{~T}_{8}\left(6 \mathrm{tha}^{-1}\right.$ Aspilia africana $+75 \mathrm{~kg} \mathrm{ha}^{-1} \mathrm{NPK}+$ $50 \mathrm{~kg} \mathrm{ha}^{-1}$ Urea) gave the highest. However, the other treatments also did better than the control. Organic residues have the ability to create conducive environs for crops to thrive better apart from their ability to also supply certain nutrients to soil. They could improve soil structure, reduces evaporation, thereby increasing moisture availability as well as regulate soil temperature. All of these coupled with the NPK application gave $\mathrm{T}_{8}$ and $\mathrm{T}_{9}$ an edge over other treatment combinations. Fig. 2 compares the yield of okra at both sides. From the chart, site 1 gave higher yield than site 2 with $\mathrm{T}_{5}$, $\mathrm{T}_{6}, \mathrm{~T}_{7}, \mathrm{~T}_{8}$ and $\mathrm{T}_{9}$. This could be because the soil at site 2 has a higher clay content than set 1 , clays are colloidal materials and have the ability to hold on to soil nutrients particularly $\mathrm{P}$ and exchangeable cations. When this happens, the nutrients are no longer available for plant use. This result confirms the findings of Akande et al. [8] and Uddin et al. [18] that application of organic material could ameliorate soil nutrients to improve crop production. 


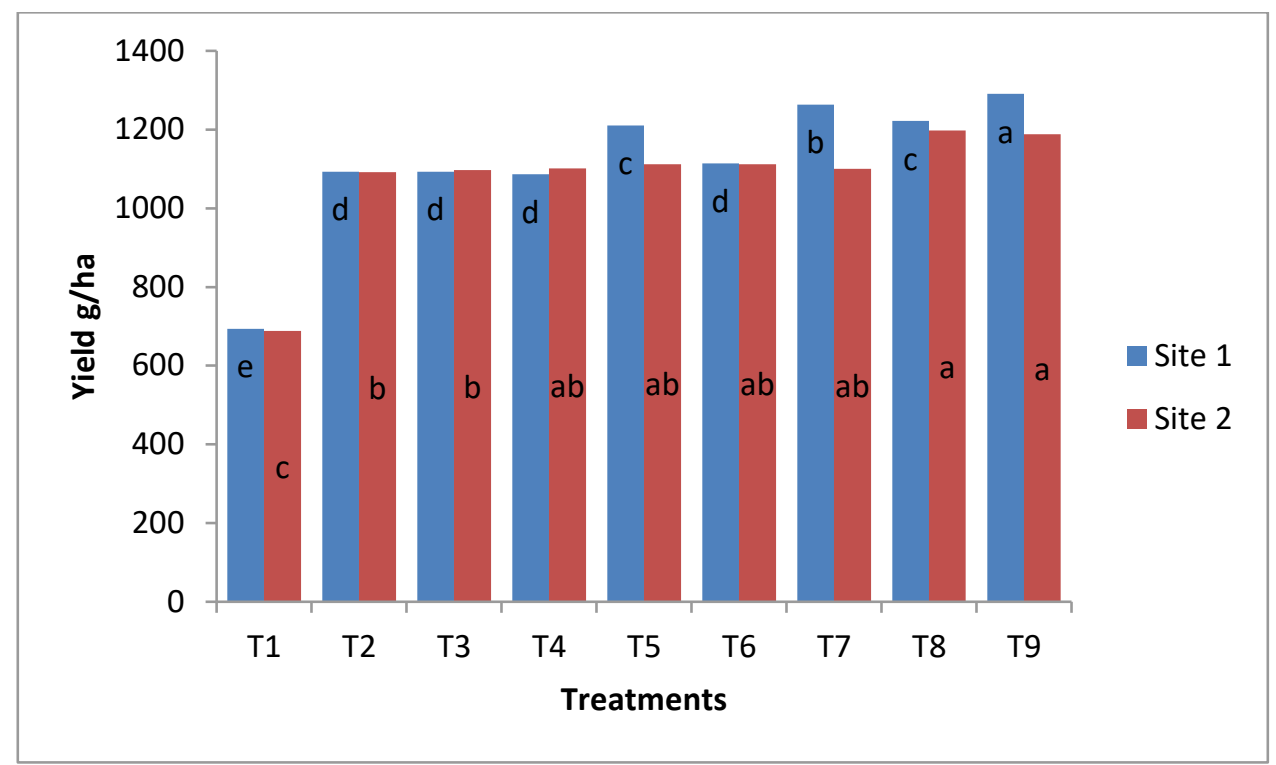

Figure 1. Effect of Organic Mulch and Inorganic Fertilizer on yield of okra.

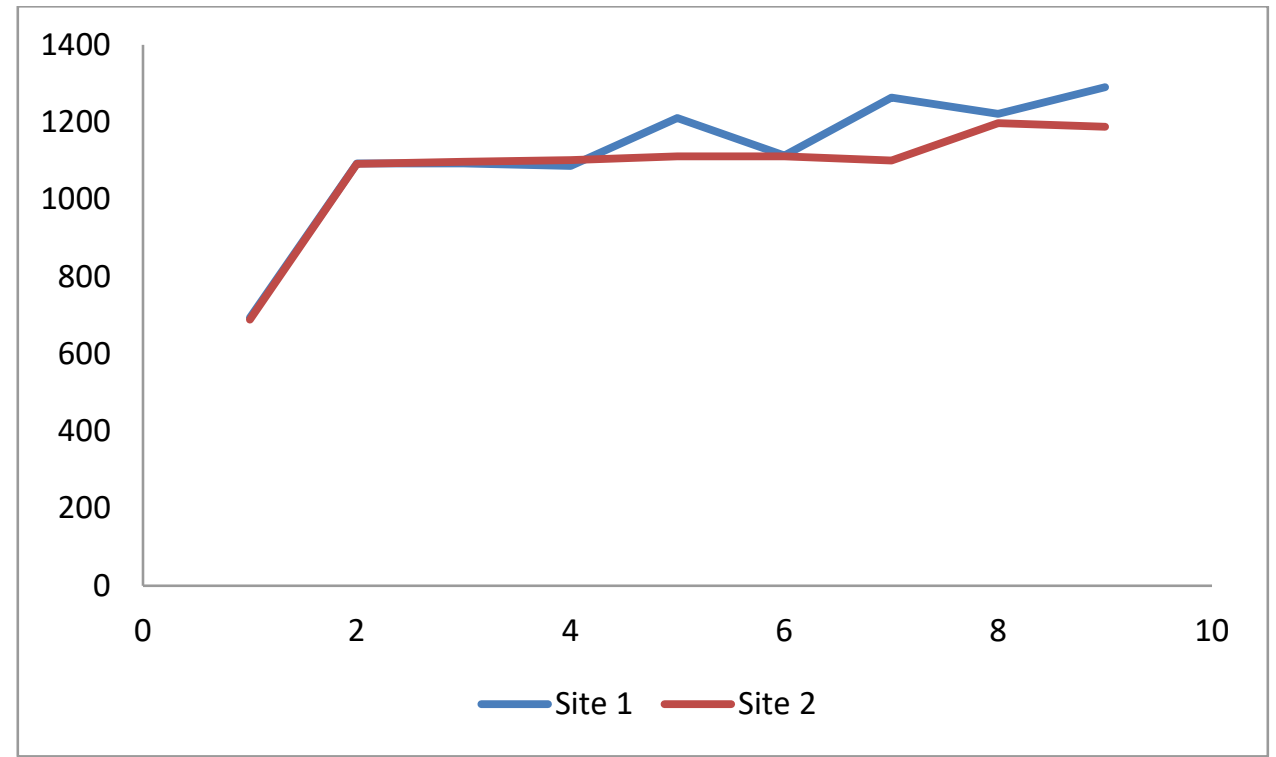

Figure 2. Comparism between Site 1 and Site 2 on yield of okra.

\section{Conclusion}

After the investigation, it was concluded that okra responds well to the application of organic residues of Gliricidia sepium and Aspilia africana particularly when combined with inorganic fertilizers. The inorganic fertilizers make nutrient available in fast and large amount which is important for plant at the early stage of growth, while the organic residues create a favorable condition for plant to thrive well and also release nutrients slowly which can be used by plant at a later period of development.

\section{Conflict of Interest}

The authors declare that there is no conflict of interest. 


\section{References}

[1] S. Ardis, Grown in South Carolina: Okra, 2015. [Online] Available: https://www.thestate.com/living/food-drink/article32312634.html.

[2] B. Polomski, D. Shaughnessy, P. Smith, Okra factsheet, Home \& Garden information Center, Clemson Cooperative extension, 2003. [Online] Available: https://hgic.clemson.edu/factsheet/okra/

[3] E.A. Akinrinde, G.O. Obigbesan, Evaluation of the fertility status of selected soils for crop production on five ecological zones of Nigeria. Proceedings of the 26th Annual Conference of Soils Science Society of Nigeria, October 30-November 3, 2000, Ibadan, Nigeria, 2000, pp. 279-288.

[4] F.N. Emuh, A.E. Ofuoku, E. Oyefia, Effect of Intercropping Okra (Hibiscus esclentus) with Pumpkin (Curcubita maxima Dutch ex Lam) on Some Growth Parameters and Economic Yield of Maize (Zea mays) and Maximization of Land Use in a Fadama Soil. Research Journal of Biological Sciences. 1 (2006) 50-54.

[5] H.F. Gemede et al., Nutritional quality and health benefits of okra (Abelmoschus esculentus): A Review, J. Food Process Technol. 6 (2015) 458. Doi: 10.4172/2157-7110.1000458.

[6] K. Ibeawuchi, Intercropping a food production strategy for resource poor farmers, Nature and Science. 5(1) (2007) 46-49.

[7] R.L. Walker, I.G. Burns, J. Moorby, Responses of plant growth rate to nitrogen supply: a comparison of relative addition and $\mathrm{N}$ interruption treatments, Journal of Experimental Botany. 52(355) (2001) 309-317.

[8] M.O. Akande et al., Response of okra to organic and inorganic fertilization, Nature and Science. 8 (11) (2010) 261-266.

[9] Mosaic Fertilizer Technology Research Centre (MFTRC), 2013. Fertilizer Research Centre, the University of Adelaide Australia.

[10] National Research Council, (NRC), 2008 "Okra". Lost Crops of Africa: Volume II: Vegetables. Lost Crops of Africa. 2. National Academies Press. ISBN 978-0-309-10333-6.

[11] O.O. Akingbola, G.O. Dayo-Olagbende, Green manuring to a better soil physical condition, Agri. Res. Tech.: Open Access J. 11(3) (2017) 555813.

[12] O.T. Ayoola, E.A. Makinde, Maize growth, yield and soil nutrients changes with N-enriched organic fertilizer. African Journal of Food Agriculture Nutrition and Developments. 9(1) (2009) 580-592.

[13] S.O. Omotoso, O.S. Shittu, Effect of NPK fertilizer rates and method of application on growth and yield of okra (Abelmoschus esculentus (L.) Moench) at Ado-Ekiti Southwestern, Nigeria, International Journal of Agricultural Research. 2 (2007) 614-619.

[14] T.M. Agbede, A.O Adekiya, Effect of wood ash, poultry manure and NPK fertilizer on soil and leaf nutrient composition, growth and yield of okra (Abelmoschus esculentus), Emir. J. Food Agric. 24(4) (2012) 314-321.

[15] U.N. Uka, K.S. Chukwuka., M. Iwuagwu, Relative effect of organic and inorganic fertilizers on the growth of Okra [Abelmoschusesculentus (L). Monech], J. Agric. Sciences. 58(3) (2013) 159-166.

[16] Z.A. Firoz, Impact of nitrogen and phosphorus on the growth and yield of okra [Abelmoschus esculentus (L)] in hile slope conditions, Bangladesh Journal of Agric. Research. 34(4) (2009).

[17] Economic Commission of Africa, State of the Environment in Africa. Economic Commission of Africa, P.O.Box 3001, Addis Ababa, Ethiopia, ECA/FSSDD/01/06, 2001.

[18] M.K. Uddin et al., Growth response of eight tropical turfgrass species to salinity, Afr. J. Biotech. 8(21) (2009) 5799-5806. 